\title{
Xanthotoxin and Other Furanocoumarins as Phytoalexins in Pastinaca sativa L. roots
}

\author{
Fatma M. Al-Barwani and Elsadig A. Eltayeb
}

Department of Biology, College of Science, Sultan Qaboos University, P.O. Box 36, Al Khod 123, Muscat, Sultanate of Oman, Email: eatayeb@squ.edu.om.

اللسلثوتوكسين والفيورلنوكيوماربنت الأخرى كمركبت فيتو ألهسينية في جنور نبلت البلسنيكاسلتفالم

\section{فلمة محمد البرولي والصام عبدا \المليب}

\author{
خلاصة : أثبتت نتائج هذه الدرلسة أن الفيورلنوكيومارينات: للسورالين، اللسانثوتوكسين، الأيسويمبينيلين،

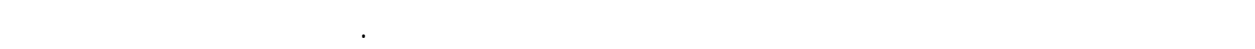

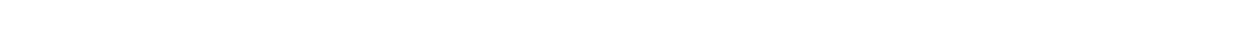

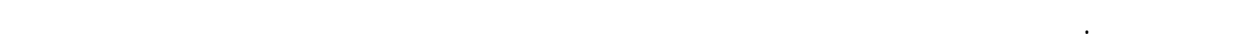

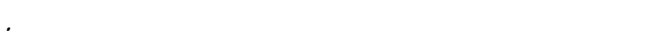

\begin{abstract}
Our results confirm the presence of the furanocoumarins psoralen, xanthotoxin, isopimpinellin, angelicin and bergapten as normal constituents of Pastinaca sativa roots. However, the amounts of these compounds were increased in induced roots. The amount of increase in the induced roots varied depending on the inducing agent and time of incubation. In addition the results show for the first time the presence of pimpinellin and isobergapten as constitutive antifungal compounds in $P$. sativa roots.
\end{abstract}

KEYWORDS: Pastinaca sativa, angelicin, psoralen, isopimpinellin, bergapten, pimpinellin, isobergapten, antifungal compounds.

\section{Introduction}

M

any workers have reported elicitation of phytoalexins by various biotic factors. The most widely

used and natural way for the induction of phytoalexin production is by fungal infection. In addition to biotic elicitors, salts of heavy metals and UV-light have commonly been used to elicit phytoalexins in many plants.

Different elicitors vary in their ability to induce phytoalexins depending on the plants induced and the phytoalexin produced. For example, ultraviolet radiation was found by Mercier et al. (1993) to be the only 


\section{FATMA M. AL-BARAWANI and ELSADIG ELTAYEB}

elicitor effective in eliciting the accumulation of the carrot phytoalexin, 6-methoxymellein (1) in carrot root slices at cold storage temperatures, while Edwards and Strange (1991) in their test of the ability of various biotic and abiotic agents, found that UV light and heavy metals only resulted in low levels of accumulation in groundnut leaflets. On the other hand, wounding by detaching leaflets from plants and inoculation of groundnut (Arachis hypogaea L.) leaflets with non-pathogenic fungi as well as naturally infected plants with major fungal pathogens resulted in the elicitation of phytoalexin response in groundnut with variation in the yield according to the challenging organism (Subba Rao and Strange 1994).

Parsnips are known to contain at least six furanocoumarins namely, xanthotoxin (2), bergapten (3), isopimpinellin (4), angelicin (5), psoralen (6) and (7) imperatorin (Johnson et al., 1973; Berenbaum et al., 1984; Desjardins et al., 1989; Ekiert and Gomólka, 2000). Johnson and co-workers (1973), however, have established that xanthotoxin is a phytoalexin in parsnip roots by demonstrating its 20 -fold induction in the roots inoculated with several fungi nonpathogenic to parsnip.

In this study, phytoalexin induction in P. sativa was investigated using fungi and the abiotic elicitor $\mathrm{CuCl}_{2}$. Quantitative analysis using HPLC was used to compare the effectiveness of these elicitors in inducing phytoalexins. Time-course accumulation of phytoalexins was also followed by HPLC.

\section{Materials and Methods}

\subsection{Plant material and Fungi}

Parsnip roots purchased from a local market (cultivar unknown) were surface sterilized in $1 \%$ sodium hypochlorite, and then rinsed twice with distilled water before use.

Dreschslera sorkiniana Sacc. Fusarium spp. and Alternaria spp. were obtained from the College of Agriculture, Sultan Qaboos University, Muscat, Oman.

Fungi were grown on Petri dishes containing potato-dextrose agar medium and were incubated at 24 ${ }^{\circ} \mathrm{C}$. Spore suspensions were obtained by flooding cultures that produced spores or conidia with deionized water containing drops of Tween-20 and gently scraping the surface. Mycelial fragments were removed by passing the spore suspensions through layers of lens tissue and the density was adjusted to approximately $1.0 \times 10^{6}$ spores $/ \mathrm{ml}$ with the aid of a haemocytometer.

\subsection{Chemicals}

The following standards were used for TLC and HPLC analysis: isopimpinellin from Carl Roth (Karlsruhe, Germany); psoralen, xanthotoxin and bergapten from Aldrich (Sigma-Aldrich Chemie Gmbh, Steinheim, Germany) and angelicin from Sigma (Sigma-Aldrich Chemie Gmbh, Steinheim, Germany). Only HPLC grade solvents were used for HPLC analysis.

\subsection{Induction of Phytoalexins}

\subsubsection{Chemical Induction}

Parsnip roots were chemically induced with a $50 \mu 1$ aliquot of $10 \mathrm{mM} \mathrm{CuCl}_{2}$ containing drops of Tween-20, placed on the fresh slices of sterilized root in sterile Petri dishes lined with moistened filter paper. The Petri dishes were then sealed with Para film and incubated in a humid environment at $24{ }^{\circ} \mathrm{C}$. The control slices received water containing drops of Tween-20 but were otherwise treated in the same way. After $48 \mathrm{hr}$ incubation, the slices were harvested for the determination of phytoalexin production.

\subsubsection{Biotic Induction}

Biotic induction was achieved by placing freshly sliced parsnip root disks on Petri dishes containing a moistened filter paper. An agar inoculum plug ( $5 \mathrm{~mm}$ diameter), mycelial side down, was then placed in the center core of each disk and incubated as above. Inoculum plugs were cut from the growing margins of not more than 10 day-old cultures of a fungus. Control slices received agar plugs without fungus (photo 1). 


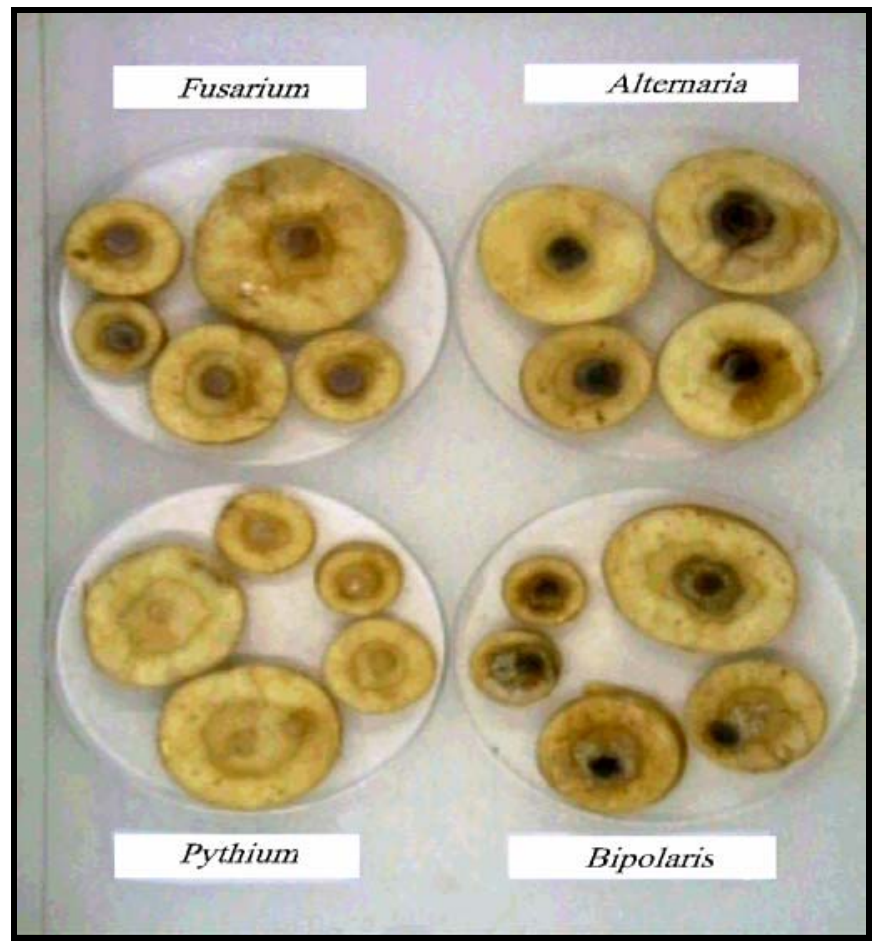

Photo 1. Induction of Pastinaca sativa root with 4 pathogenic fungi after 2 days incubation at $24^{\circ} \mathrm{C}$ in a humid environment.

\subsection{Extraction and Detection of Phytoalexins}

Induced and control parsnip slices were extracted twice overnight with methanol. The dried extracts were then dissolved in $100 \%$ methanol for phytoalexin analysis.

A thin layer chromatography (TLC)-Cladosporium bioassay was used for the detection and screening of phytoalexins. About $20 \mu \mathrm{l}$ aliquot of the concentrated extracts were applied to TLC plates (Si gel $60 \mathrm{f}$ $254,20 \times 20 \mathrm{~cm})$. The plates were developed in either chloroform-methanol (97:3), or in toluene-ethyl acetate (1:1) and air dried. The developed TLC plates were sprayed with a dense spore suspension of Dreschslera sorkiniana in a nutrient solution. The plates were then incubated at $24{ }^{\circ} \mathrm{C}$ in a moist chamber for 2-5 days. The antifungal inhibition zones were observed and the $\mathrm{R}_{\mathrm{f}}$ values calculated.

The spore suspension nutrient solution was prepared by mixing $20 \mathrm{ml}$ salt solution and $10 \mathrm{ml}$ of $15 \%$ glucose solution. $1 \mathrm{~L}$ of salt solution contained $7 \mathrm{~g} \mathrm{KH}_{2} \mathrm{PO}_{4}, 4 \mathrm{~g} \mathrm{KNO}, 3 \mathrm{~g} \mathrm{NaHPO} \mathrm{N}_{4} .2 \mathrm{H}_{2} \mathrm{O}, 1 \mathrm{~g} \mathrm{MgSO} .7 \mathrm{H}_{2} \mathrm{O}$.

\subsection{Identification and Quantification of Phytoalexins}

After the TLC bioassay, using the above mentioned solvent systems, the regions of thin layer chromatograms corresponding to the inhibitory zones were scraped off and eluted with $100 \%$ methanol. Identification of the antifungal compounds was carried out by Co-TLC and Co-HPLC with authentic standards or by comparison of $\mathrm{R}_{\mathrm{f}}, \mathrm{R}_{\mathrm{t}}$ values and UV spectra with literature. 
FATMA M. AL-BARAWANI and ELSADIG ELTAYEB<smiles>COc1cc(O)c2c(c1)C[C@@H](C)OC2=O</smiles>

(1) 6-Methoxymellein<smiles>COc1c2occc2cc2ccc(=O)oc12</smiles>

(2) Xanthotoxin<smiles>O=c1ccc2ccc3occc3c2o1</smiles>

(5) Angelicin<smiles>COc1cc2ccc(=O)oc2c2ccoc12</smiles>

(8) Sphondin<smiles>COc1c2ccoc2cc2oc(=O)ccc12</smiles>

(3) Bergapten<smiles>COc1c2ccoc2c(OC)c2oc(=O)ccc12</smiles>

(4) Isopimpinellin<smiles>CC(C)=CCOc1c2occc2cc2ccc(=O)oc12</smiles>

(7) Imperatorin<smiles>COc1cc2occc2c2oc(=O)ccc12</smiles>

(10) Isobergapten<smiles>CC(C)=CCOc1c2ccoc2cc2oc(=O)ccc12</smiles>

(11) Isoimperatorin

Figure 1. Chemical structures of some phytoalexins 


\section{PHYTOALEXINS IN PASTINACA SATIVA L. ROOTS}

\subsubsection{Thin Layer Chromatography}

Purification of the eluted antifungal compounds was carried out on TLC plates (Si gel $60 \mathrm{f}-254,20 \mathrm{X}$ $20 \mathrm{~cm}$ ). The chromatograms were developed at room temperature using the following solvent systems:

A) Chloroform: Ethyl acetate (2:1).

B) Chloroform.

C) Toluene: Ethyl acetate (1:1)

Following evaporation of the solvent, the thin layer plates were observed under UV light and the $\mathrm{R}_{\mathrm{f}}$ values were noted. Compounds were identified from comparison of their $\mathrm{R}_{\mathrm{f}}$ values and fluorescence under UV light $(254 \mathrm{~nm})$ with standards run parallel to the samples.

\subsubsection{HPLC analysis}

A Waters gradient system consisting of Waters 626 pump, a Model 600s system controller, a Waters 717 plus auto-sampler and a Waters in-line degasser was used for the separation and identification of antifungal compounds from the crude extracts or from the eluted TLC bands. For UV detection a Waters 996 photodiode array detector was used at $254 \mathrm{~nm}$. The gradient separations were carried out using a Waters Spherisorb ODS-II $(3 \mu \mathrm{m})$ cartridge column $(100 \times 4.5 \mathrm{~mm}$ I.D. $)$. Solvent A was tetrahydrofuran $-\mathrm{H}_{2} \mathrm{O}$ (3.5:96.5) and solvent $\mathrm{B}$ was $100 \% \mathrm{MeOH}$. The gradient profile was as follows: $0-20 \mathrm{~min}, 25 \% \mathrm{~B}$ in A (isocratic); $20-40 \mathrm{~min}, 25-45 \% \mathrm{~B}$ in A (linear gradient); $45-55 \mathrm{~min}, 45 \% \mathrm{~B}$ in A (isocratic). All standards and samples were dissolved in $\mathrm{MeOH}$ and the injection volume was $10 \mu \mathrm{l}$. Peaks of sample and standard compounds were identified and compared by on-line UV detection at $254 \mathrm{~nm}$.

\subsection{Antifungal Activity}

\subsubsection{Slide Bioassay}

Samples $25 \mu \mathrm{l}$ of a series of concentration of the antifungal compounds dissolved in methanol were placed on a glass microscope slide within a circle of vaseline. These were left to dry before $50 \mu \mathrm{l}$ of spore suspension was added. Slides were incubated in a plastic container lined with moist tissue paper at $25^{\circ} \mathrm{C}$ in the dark for 16 to $24 \mathrm{hr}$. Spore germination and germ tube elongation were determined by microscopic observation.

\subsubsection{Paper-disk Method}

Paper discs $(0.3 \mathrm{~cm}$ diam.) were loaded with a known amount of the antifungal compound in absolute methanol (maximum volume, $20 \mu \mathrm{l}$ ). Control disks were treated with $20 \mu \mathrm{l}$ of methanol alone. In all cases, sufficient time was allowed for the methanol to evaporate before transferring the discs to agar surfaces. Discs were arranged in Potato Dextrose Agar (PDA) Petri plates, which had been inoculated with the test fungi. Plates were incubated at $25{ }^{\circ} \mathrm{C}$ and diameters of inhibiting zones were measured after $20 \mathrm{hr}$. Percentage inhibition was calculated as follows:

$100-\{$ mycelial growth in treated/ mycelial growth in control $\times 100\}$

$\mathrm{EC}_{50}$ values were calculated from the regression lines obtained from plots of concentration versus percent inhibition.

\section{Results}

\subsection{Chemical Induction}

Strong antifungal zones on TLC were produced in both fungal and copper chloride treated parsnip root slices that were also present in the control slices. These compounds were identified by on-line UV detection (Figure 2) and found to be the previously reported furanocoumarins xanthotoxin, isopimpinellin, angelicin and bergapten (Desjardins et al., 1989; Johnson et al., 1973; Ekiert and Gomólka, 2000). Another 


\section{FATMA M. AL-BARAWANI and ELSADIG ELTAYEB}

previously reported compound, sphondin $(8)\left(R_{t} 30\right)$ and two compounds which have not been reported from parsnip roots before, pimpinellin (9) $\left(R_{t} 41\right)$ and isobergapetn $(\mathbf{1 0}),\left(R_{t} 43\right)$, were identified by their properties under UV light and by comparing their retention times and UV spectra with literature values (Erdelmeier et al., 1985). However, isoimperatorin (11), earlier reported to be a constitutive component of parsnip roots was not detected in any of our samples, but another unidentified compound was detected at $R_{t}$ 37. Surprisingly, psoralen was detected only in the control samples at very low concentration and was absent from the treated samples.



Figure 2. Gradient HPLC separation of furanocoumarins from Pastinaca sativa root. Separations were carried out using a Waters Spherisorb ODS-II $(3 \mu \mathrm{m})$ cartridge column (100 x $4.5 \mathrm{~mm}$ I.D.). Solvent A was tetrahydrofuran $-\mathrm{H}_{2} \mathrm{O}(3.5: 96.5)$ and solvent $\mathrm{B}$ was $100 \% \mathrm{MeOH}$. P: psoralen; X: xanthotoxin; A: angelicin; B: bergapten; IP: isopimpinellin. $R_{t} 29.9$ Sphondin; Rt 43.2: isobergapten; $R_{t} 41.1$ : pimpinellin.

Quantitative HPLC analysis indicated that the amounts of all of these compounds increased in the induced slices but at different levels (Figure 3). The largest increase is in angelicin which increased by 34 fold in the chemically induced slices from $0.015 \mathrm{mg} / \mathrm{g}$ fresh weight in the control to $0.51 \mathrm{mg} / \mathrm{g}$ fresh weight followed by xanthotoxin which increased by 29 fold in the chemically induced slices from $0.05 \mathrm{mg} / \mathrm{g}$ fresh weight in the control to $1.48 \mathrm{mg} / \mathrm{g}$ fresh weight (Table 1).

Table 1. Increased furanocoumarin concentrations in Pastinaca sativa L. root after 1 day induction with $\mathrm{CuCl}_{2}$.

\begin{tabular}{|c|c|c|c|}
\hline \multirow{2}{*}{ Coumarin } & \multicolumn{2}{|c|}{$\mathrm{mg} / \mathrm{g}$ of Fresh weight } & \multirow{2}{*}{$\begin{array}{c}\text { Increase } \\
\text { Test/Control }\end{array}$} \\
\cline { 2 - 3 } & Control & Test & - \\
\hline Psoralen & 0.001 & n.d.* & 29 \\
\hline Xanthotoxin & 0.051 & 1.475 & 12 \\
\hline Isopimpinellin & 0.033 & 0.392 & 7 \\
\hline Bergapten & 0.025 & 0.172 & 34 \\
\hline Angelicin & 0.015 & 0.51 & \\
\hline
\end{tabular}

* Not determined 


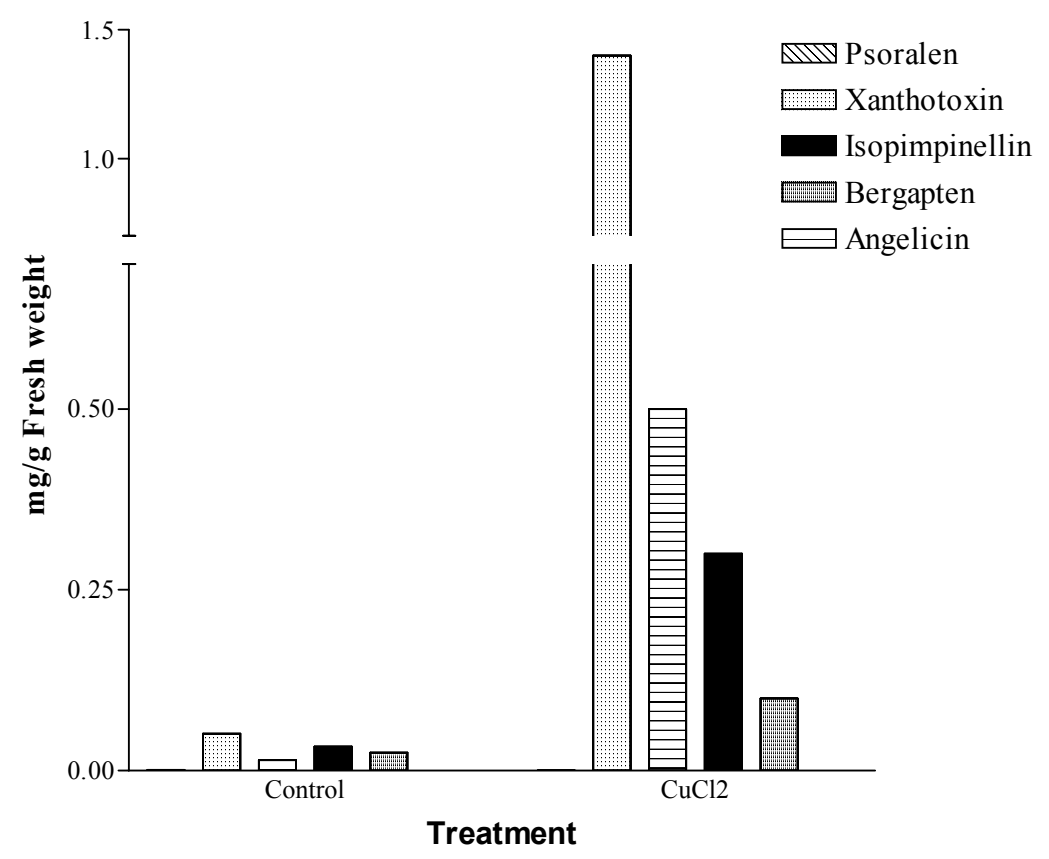

Figure 3. Furanocoumarin content in Pastinaca sativa L. root after one day incubation with $\mathrm{CuCl}_{2}$.

\subsection{Biotic Induction}

Parsnip roots inoculated with four different fungi resulted in increased levels of the furanocoumarins psoralen, xanthotoxin, isopimpinellin, bergapten and angelicin (Figure 4). The five furanocoumarins were present in small amounts in control parsnip roots. Both the amounts and proportions of the furanocoumarins varied with the type of elicitor used. The largest increase in furanocoumarin content was observed in parsnip roots inoculated with the fungus $B$. sorkiniana, while the smallest increase was in parsnip roots inoculated with Alternaria spp. In all treatments, xanthotoxin was the major phytoalexin induced in parsnip roots and was the major constituent of the control roots.

Xanthotoxin, angelicin and psoralen were the major phytoaleins induced in parsnip roots by the fungus $B$. sorkiniana. Treatment with copper chloride however, resulted in the accumulation of xanthotoxin and isopimpinellin as the major induced compounds, while psoralen was not detected in these discs. In addition, three other furanocoumarins, sphondin, pimpinellin and isobergapten were found in all treatments including the control but the amounts of these compounds were not determined.

\subsection{Time-course Accumulation of Phytoalexins}

Changes in furanocoumarin content in parsnip root discs after induction with copper chloride solution over a period of six days are shown in Figure 5. Increase in furanocoumarin concentrations was observed from day 1 after induction. At this time, xanthotoxin and angelicin reached their maximum concentrations of 1.48 and $0.51 \mathrm{mg} / \mathrm{g}$ fresh weight respectively, followed by a rapid decline at day 2 . While isopimpinellin and bergapten continued to increase to their maximum 0.60 and $0.26 \mathrm{mg} / \mathrm{g}$ fresh weight, respectively, at day 2. Traces of psoralen were first observed at day 5 , which increased to $0.052 \mathrm{mg} / \mathrm{g}$ fresh weight at day 6 .

Xanthotoxin remained the dominant furanocoumarin throughout the experiments. 
FATMA M. AL-BARAWANI and ELSADIG ELTAYEB

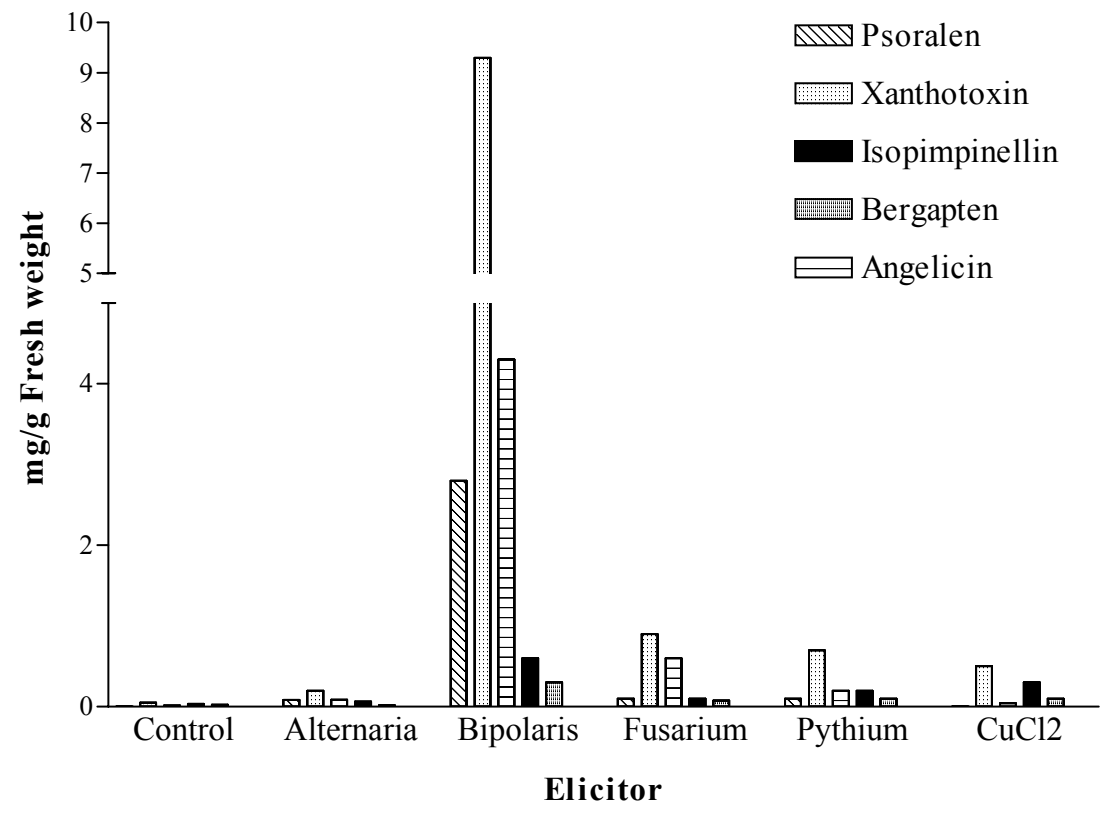

Figure 4. Furanocoumarin content in Pastinaca sativa L. root treated with different elicitors elecicitors after 3 days incubation .

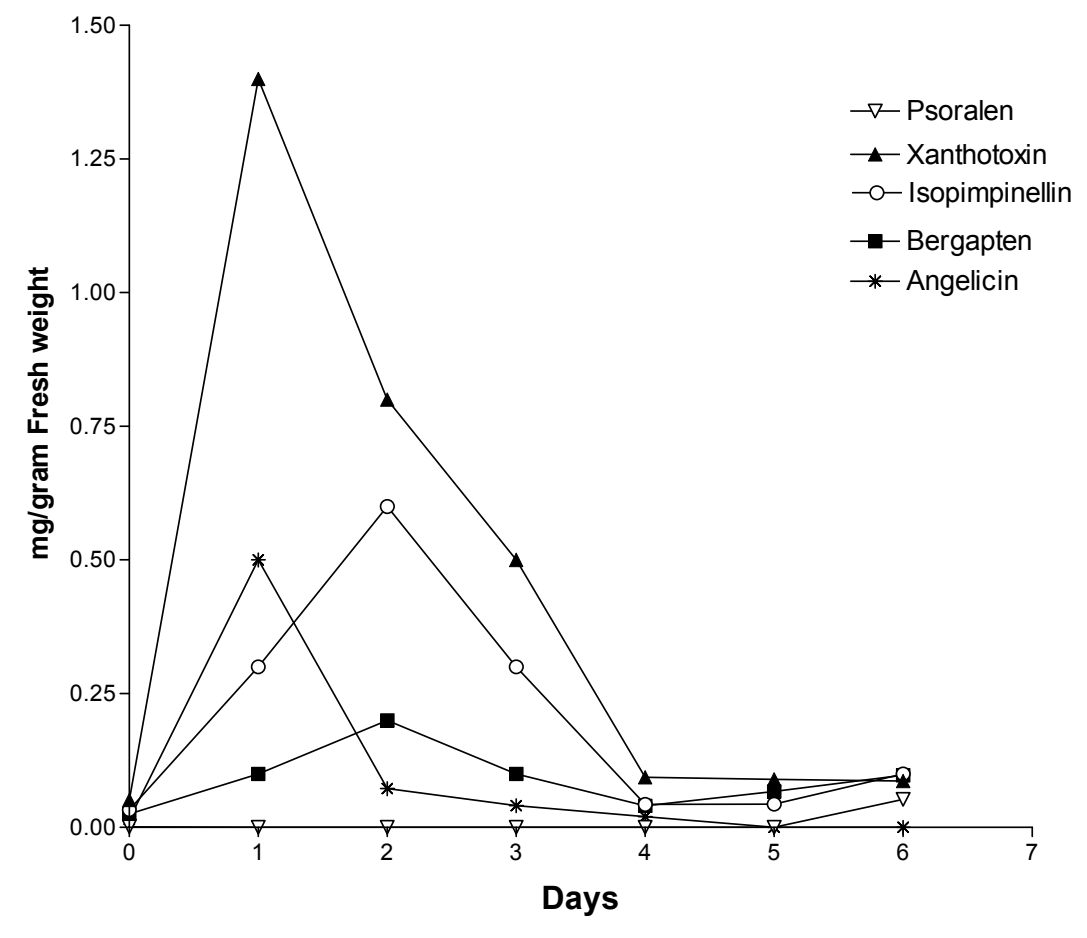

Incubation time

Figure 5. Time course accumulation of furanocoumarin Phytoalexins sativa L. roots induced with copper chloride. 


\section{PHYTOALEXINS IN PASTINACA SATIVA L. ROOTS}

\subsection{Antifungal Activity}

Three pathogenic fungi: Alternaria spp. Bipolaris spp. and Fusarium spp. were tested for their sensitivity towards three antifungal compounds detected in $P$. sativa. The fungitoxic activity of the three compounds on the spore germination and the mycelial growth on agar plates are shown in Table 2.

All the tested furanocoumarins had relatively high $\mathrm{EC}_{50}$ values on both spore germination and mycelial growth of the tested organisms. The tested compounds inhibited spore germination of Alternaria and Bipolaris more effectively than mycelial growth of Alternaria spp. but were most effective in inhibiting mycelial growth of Fusarium spp.

Table 2. Effective concentrations of furanocoumarins resulting in 50\% inhibition of conidia germination and growth inhibition for three fungi.

\begin{tabular}{|l|l|l|l|l|}
\hline \multirow{3}{*}{ Compound } & \multicolumn{4}{|c|}{$\mathrm{EC}_{50}(\mu \mathrm{g} / \mathrm{ml})$} \\
\cline { 2 - 5 } & \multicolumn{1}{|c|}{ Conidia germination } & \multicolumn{2}{c|}{ Mycelial growth } \\
\cline { 2 - 5 } & Alternaria & Bipolaris & Alternaria & Fusarium \\
\hline Xanthotoxin & 1920 & 4320 & 5560 & 195 \\
\hline Bergapten & n.d. $^{*}$ & 1920 & 6010 & n.d.* $^{*}$ \\
\hline Angelicin & 3460 & n.d. $^{*}$ & 6120 & 115 \\
\hline
\end{tabular}

* Not determined

The high $\mathrm{EC}_{50}$ values of the furanocoumarins obtained here for mycelial growth of Alternaria spp. are comparable to the values obtained by Afek et al. (1995a and b) for celery.

\section{Discussion}

Johnson et al. (1973) reported the production of xanthotoxin as a phytoalexin of Pastinaca sativa roots inoculated with several fungi nonpathogenic to parsnip. This finding was confirmed in this study but the amounts of xanthotoxin reported here were larger than those reported by Johnson and his co-workers. Induction of parsnip roots with $\mathrm{CuCl}_{2}$ in the present study resulted in an increase in the amounts of xanthotoxin by 29- fold compared to 20- fold. Although xanthotoxin was found to be the major furanocoumarin component of parsnip root both constitutively $(0.051 \mathrm{mg} / \mathrm{g}$ fresh weight $)$ and $\mathrm{CuCl}_{2}$ induced $(1.47 \mathrm{mg} / \mathrm{g}$ fresh weight), the present study shows that xanthotoxin is not the only induced compound in parsnip roots. All other reported constitutive furanocoumarins of parsnip root, with the exception of psoralen and imperatorin, were found to increase similarly in the induced samples. The induced furanocoumarins are bergapten, isopimpinellin, angelicin and sphondin. A large increase in angelicin, psoralen, isopimpinellin and bergapten was also observed in parsnip roots inoculated with $B$. sorkiniana. This is therefore the first confirmation that psoralen, isopimpinellin, bergapten and angelicin are phytoalexins in parsnip roots with a similar effect to xanthotoxin.

The large increase in furanocoumarins as a result of induction is in agreement with the earlier reports on the response of the Umbelliferae to phytoalexin induction. For example, Chaudhary et al. (1985) considered the linear furanocoumarins, psoralen (6), xanthotoxin and bergapten (7) to be phytoalexins of celery (Apium graveolens) by reporting that diseased celery infected with the fungus Sclerotinia sclerotiorum had greatly increased the levels of these compounds that are normally found in healthy celery (Beier and Oertli, 1983; Chaudhary et al., 1985; Ashwood-Smith et al., 1986; Trumble et al., 1990).

Similarly, Al-Barwani (2002) in her survey of phytoalexins in a number of umbelliferous species found that the majority of the species studied produce high levels of furanocoumarins as a result of induction. In many cases, the induced compounds were also found constitutively in small amounts in the untreated tissue. 


\section{FATMA M. AL-BARAWANI and ELSADIG ELTAYEB}

The use of a gradient HPLC separation of furanocoumarins with on-line UV detection and Spherisorb ODS II $(3 \mu \mathrm{m})$ column at the described gradient profile (Erdelmeier et al., 1985) in this study has allowed the separation and identification of two more furanocoumarins in Pastinaca sativa roots. These two compounds, pimpinellin and isobergapten were not quantified; hence their concentrations in the control and induced samples were not compared. Whether they also act as phytoalexins in parsnip requires further investigation.

Variation in the amount and proportion of phytoalexins was observed in our study with $P$. sativa roots following treatment with various biotic and abiotic elicitors. The biotic elicitor, $B$. sorkiniana was found to be the most effective. Parsnip roots induced with other fungi resulted in low levels of furanocoumarin accumulation while the heavy metal copper chloride was found to be less effective.

Time course studies of phytoalexin accumulation in $P$. sativa root showed variation in the rate of accumulation of the different compounds using the same non-specific elicitor, copper chloride. Thus the major phytoalexins, xanthotoxin, and angelicin accumulated at day 1 while isopimpinellin and bergapten accumulated at day 2 after elicitation. This variation in the rate of accumulation of different phytoalexins of the same species was also observed elsewhere, e.g. in Conium maculatum L. leaves following elicitation with $\mathrm{CuCl}_{2}$ (Al-Barwani and Eltayeb, 2004). In both species, psoralen was not detected until day 6 or 7 after elicitation. This was accompanied by a decrease in the levels of other coumarins. This is probably due to a decrease in the rate of transformation of psoralen (the presumed biosynthetic precursor of the other furanocoumarins) to other alkoxy-furanocoumarins. This was similarly observed in celery following elicitation with copper sulfate in cold conditions (Beier and Oertli, 1983).

While the concentrations of xanthotoxin and angelicin in the induced roots of Pastinaca sativa were found to be lower than their $\mathrm{EC}_{50}$ values on mycelial growth of Alternaria and conidia germination of both Alternaria and Bipolaris, the concentrations of the two compounds were well above the concentrations required for $50 \%$ inhibition of mycelial growth of Fusarium. Thus, despite their high $\mathrm{EC}_{50}$ values, these compounds are induced in the Umbelliferae at levels high enough to cause inhibition of both conidia germination and mycelial growth of some pathogenic fungi.

However, it should be noted that the $\mathrm{EC}_{50}$ values were compared with the concentrations in the chemically induced tissues. Since variation in the amounts of phytoalexins with the use of different elicitors was observed in the present study, the concentration of these compounds may be greater in infected tissue and thus play a role in disease resistance. To prove the role of these compounds in disease resistance, further studies are required to demonstrate that the substances are present at the right time, in the right place and in sufficient quantity to cause any observed inhibition of microbial colonization of plant tissue (Mansfield, 2000).

\section{Acknowledgment}

F. Al-Barwani wishes to acknowledge the supervision of the late Prof J. Harborne under whose excellent guidance this work was partially done at the University of Reading, U.K.

\section{References}

AFEK, U., AHARONI, N. and CARMELI, S. 1995b. The involvement of marmesin in celery resistance to pathogens during storage and the effect of temperature on its concentration. Phytopathology. 85: 1033-1036.

AFEK, U., CARMELI, S. and AHARONI, N. 1995a. Columbianetin, a phytoalexin associated with celery resistance to pathogen during storage. Phytochemistry. 39: 1347-1350.

Al-BARWANI, F.M. 2002. Phytoalexin induction in the Umbelliferae. Ph.D. Thesis, University of Reading, Reading. UK. 
Al-BARWANI, F.M., and ELTAYEB, E.A. 2004. Antifungal compounds from induced Conium maculatum L. Plants. Biochemical Systematics and Ecology, 32: 1097-1108.

ASHWOOD-SMITH, M.J., CESKA, O., CHAUDHARY, S.K., WARRINGTON, P.J. and WOODCOCK, P. 1986. Detection of furanocoumarins in plants and plant products with ultrasensitive biological photoassay employing a DNA-Repair-Deficient Bacterium. Journal of Chemical Ecology. 12: 915932.

BEIER, R.C. and OERTLI, E.H. 1983. Psoralen and other linear furanocoumarins as phytoalexins in celery. Phytochemistry. 22: 2595-2597.

BERENBAUM, M.R., ZANGERL, A.R. and NITAO, J.K. 1984. Furanocoumarins in seeds of wild and cultivated parsnip. Phytochemistry. 23: 1809-1810.

CHAUDHARY, S.K., CESKA, O., WARRINGTON, P.J. and ASHWOOD-SMITH, M. 1985. Increased furanocoumarin content of celery during storage. Journal of Agriculture Food and Chemistry. 33: $1153-1157$.

DESJARDINS, A.E., SPENCER, G.F., PLATTNER, R.D. and BEREMAND, M.N. 1989. Furanocoumarin phytoalexins. Trichothecene toxins and infection of Pastinaca sativa by Fusarium sporotrichiodes. Phytopathology. 79: 170-175.

EDWARDS, R. and STRANGE, R.N. 1991. Separation and identification of phytoalexins from leaves of groundnut (Archis hypogaea) and development of a method for their determination by reversed-phase high-performance liquid chromatography. Journal of Chromatography. 547: 185-193.

EKIERT, H. and GOMŌLKA, E. 2000. Furanocoumarins in Pastinaca sativa L. in vitro culture. Pharmazie. 55: 618-620.

ERDELMEIER, C.A.J., MEIER, B. and STICHER, O. 1985. Reserved-phase high-performance liquid chromatographic separation of closely related furanocoumarins. Journal of Chromatography. 346: 456-460.

JOHNSON, C., BRANNON, D.R. and KUĆ, J. 1973. Xanthotoxin: a phytoalexin of Pastinaca sativa root. Phytochemistry. 12: 2961-2962.

MANSFIELD, J.W. 2000. Antimicrobial compounds and resistance: the role of phytoalexins and phytoanticipins. In: Mechanisms of resistance to plant diseases (Slusarenko, A., Fraser, R.S.S. and van Loon L.C. eds.) pp. 325-370. Kluwer Academic Publishers, Netherlands.

MERCIER, J., ARUL, J. and CHANTAL, J. 1993. Effect of UV-C on phytoalexin accumulation and resistance to Botrytis cinerae in stored carrots. Journal of Phytopathology. 139: 17-25.

SUBBA RAO, P.V. and STRANGE, R.N. 1994 Groundnut Phytoalexins and Disease Resistance. In: Handbook of phytoalexin metabolism and action, (DANNEIL, M. and PURKAYASTHA, R.P., eds), pp 199-227. Marcel Dekker, New York.

TRUMBLE, J.J., DERECKS, W., QUIROS, F. and BEIER, C. 1990. Host plant resistance and linear furanocoumarin content of Apium Accessions. Journal of Economic Entomology. 83: 519-525.

Received 17 September 2003

Accepted 31 March 2004 